\title{
Pentingnya Mengukur Kesiapan Guru Sebagai Dasar Pembelajaran Daring Di Lembaga PAUD
}

\author{
Dinda Rizki Tiara ${ }^{1}$, Eriqa Pratiwi ${ }^{2}$ \\ PG-PAUD Universitas Trunojoyo Madura ${ }^{1}$ PG-PAUD Universitas Trunojoyo Madura ${ }^{2}$ \\ Email: dinda.rtiara@trunojoyo.ac.id ${ }^{1}$, eriqa.pratiwi@trunojoyo.ac.id ${ }^{2}$
}

\begin{abstract}
Abstrak
Kondisi pandemi menyebabkan guru harus siap beradaptasi dan melakukan pembelajaran daring. Kesiapan guru harus diukur dan menjadi dasar pengembangan pembelajaran. Penelitian yang dilakukan dengan metode literature review ini bertujuan untuk mengetahui urgensi dari mengukur kesiapan guru dalam pembelajaran daring serta mencari skala untuk mengukurnya. Hasil literature review yang dilakukan menunjukan penting untuk mengetahui kesiapan guru dalam pembelajaran daring karena akan mempengaruhi kesiapan lembaga PAUD dan keberhasilan pelaksanaan pembelajaran daring. Terdapat berbagai jenis instrument yang dapat diadaptasi untuk mengukur kesiapan guru dalam pembelajaran daring yang dapat disesuaikan dengan keadaan dari lenbaga PAUD masing - masing. Penelitian ini mengajak untuk mengukur kesiapan guru sebelum melakukan pembelajaran daring di lembaga PAUD agar hasil pembelajaran lebih optimal.
\end{abstract}

Kata kunci: kesiapan guru, pembelajaran daring, skala kesiapan guru, pembelajaran daring

\begin{abstract}
The pandemic causing teachers to be ready to adapt and undertake bold learning. Teacher readiness must be measured and the basis for developing learning. Research conducted with the literature review method and aimed to determine the urgency of measuring teacher readiness in online learning and looking for a scale to measure it. The results of the literature review conducted show the importance to know the readiness of teachers in online learning because it will affect the readiness of early childhood education institutions and the success of implementing online learning. There are various types of instruments that can be adapted to measure the readiness of teachers in online learning which can be adapted to the circumstances of the respective early childhood education institutions. This study recommends to measuring the readiness of teachers before conducting online learning at early childhood education institutions so that learning outcomes are more optimal.
\end{abstract}

Keywords: teacher readiness, online learning, teacher readiness, online learning scale

\section{PENDAHULUAN}

Pendidikan anak usia dini merupakan pendidikan yang paling penting karena usia peserta didik yang dianggap merupakan masa emas dari kehidupan manusia yaitu usia $0-6$ tahun. Pada usia hingga dua tahun pembelahan sel otak sangat cepat, setelah itu melambat dan yang terjadi hanya pembesaran sel - sel otak saja (Soetjiningsih \& Gde, 2017). Secara

Pentingnya Mengukur Kesiapan (Tiara, Pratiwi) 362 
fisik, otak anak di usia dua tahun memiliki berat $75 \%$ orang dewasa dan neuron pada anak usia dua tahun dapat terbentuk dan terhubung bila mendapatkan stimulasi yang baik dan tepat (Santrock, 2007). Pemberian stimulasi yang baik dan tepat ini dapat dilakukan oleh guru dan orangtua dalam sebuah pembelajaran. Pembelajaran yang diberikan harus sesuai dengan kebutuhan dan tingkat perkembangan anak. Sebagai seorang guru yang merupakan agen pendidikan formal anak usia dini yang memberikan stimulus dalam pembelajaran di sekolah memerlukan kompetensi tertentu. Terdapat beberapa jenis kompetensi pendidik yang harus dimiliki oleh seorang guru untuk memberikan pembelajaran yang baik dan tepat untuk anak, salah satunya adalah kompetensi pedagogik. Kompetensi pedagogik seorang guru dapat mempengaruhi bagaimana kualitas proses pembelajaran yang diberikan kepada peserta didik (Sum \& Taran, 2020). Guru harus mampu menyusun, melaksanakan, mengelola hingga mengevaluasi pembelajaran di kelasnya.

Perubahan kondisi lingkungan belajar dari yang biasanya anak datang ke sekolah menjadi tidak bisa datang ke sekolah terdakang terjadi dikarenakan suatu penyebab. Penyebab perubahan cara belajar anak saat ini adalah masa pandemik Covid - 19 (Corona Virus Disease - 19) yang memaksa guru menggunakan cara pembelajaran yang berbeda dari biasanya yaitu dengan daring. Pembelajaran daring dilakukan dengan menggunakan elektronik dalam proses pelaksanaanya. Pelaksanaan pembelajaran daring cukup banyak ditolak oleh orangtua yang memiliki anak pada usia dini karena beberapa alasan (Dong, Cao, \& Li, 2020). Selain itu terdapat pula beberapa permasalahan yang terjadi dalam pelaksanaan pembelajaran daring dimana anak terpaksa diam dan belajar di rumah, salah satunya adalah banyaknya tugas yang harus diselesaikan oleh anak (Tabi'in, 2020). Pada saat inilah guru dituntut mampu melakukan pembelajaran daring dengan baik demi menjaga kualitas pembelajaran yang mempengaruhi hasil pendidikan. Masa pandemi Covid - 19 (Corona Virus Disease - 19) yang memaksa guru menggunakan cara pembelajaran yang berbeda dari biasanya yaitu dengan daring. Pembelajaran daring dilakukan dengan menggunakan elektronik dalam proses pelaksanaanya. Pada saat inilah guru dituntut mampu melakukan pembelajaran daring dengan baik demi menjaga kualitas pembelajaran yang mempengaruhi hasil pendidikan. Selain itu berkaitan salah kode etik guru yaitu tanggung jawab dan selalu meningkatkan kapasistas dan kualitas profesinya (Samawi, 2019). Sehingga guru harus siap untuk melakukan pembelajaran secara daring.

Kesiapan yang dimaksud adalah kemampuan untuk beradaptasi dengan perubahan teknologi, pelatihan yang diselenggarakan oleh pihak lain (kolaborasi) dan keselarasan pelatihan yang diikuti dengan dilakukannya latihan secara mandiri oleh guru (Waryanto \& Setyaningrum, 2014). Hasil pelatihan yang dilakukan oleh guru dipengaruhi oleh lingkungan guru. Kepala sekolah, pelatihan yang diikuti serta bimbingan akan mempengaruhi penerapan pendekatan kolaborasi pembelajaran daring (Online Collaborative Learning/OCL) (Koo, 2008). Namun sayangnya terdapat pemikiran bahwa guru di Indonesia dirasa terlalu gagap dalam mengoperasikan teknologi untuk melakukan pembelajaran daring (Churiyah, Sholikhan, Filianti, \& Sakdiyyah, 2020). Masih ditemukannya pendidika PAUD yang belum mahir dalam menggunakan aplikasi pembelajaran (Nurdin \& Anhusadar, 2020). Hal ini menjadikan keraguan bagaimana guru dapat beradaptasi dengan kemampuan teknologi yang rendah. Selain itu kemampuan pedagogi guru PAUD dapat mempengaruhi proses pembelajaran anak (Sum \& Taran, 2020). Sehingga bila dilihat jenis kesiapan dan faktor yang memperngaruhi penting diketahui bagaiaman guru mengahadapi perubahan cara 
pelaksanaan pembelajaran. Sayangnya masih sedikit penelitian yang melihat bagaimana kesiapan guru dalam pembelajaran daring khusus lembaga pendidikan anak usia dini. Bila sebuah pembelajaran daring dilakukan tanpa mempertimbangkan kesiapan guru terdapat kemungkinan terjadi permasalahan. Sehingga dirasa perlu untuk mengetahui seberapa pentingkah mengetahui kesiapan guru dalam pembelajaran daring untuk mempertahankan pembelajaran yang berkualitas dan cara untuk melihat kesiapan guru dalam pelaksanaan pembelajaran daring.

\section{METODE PENELITIAN}

Penelitian ini menggunakan metode literature review. Metode ini digunakan untuk mencari jawaban dari pertanyaan penelitian dengan menggunakan pencarian literatur, baik skala nasional maupun internasional dan menggunakan buku ataupun berasal dari berbagai mensin pencarian. Buku dan jurnal dipilih dengan beberapa kriteria, yaitu diambil dari situs jurnal yang terakreditasi, subjek penelitiannya adalah guru, berbahasa Inggris maupun Bahasa Indonesia dan tahun terbitnya tidak lebih dari 10 tahun. Secara sistematis berikut alur penulisan literature review yaitu, studi literatur, pengumpulan data, konsep yang diteliti, konseptualisasi, analisis data, hasil dan pembahasan dan yang terakhir kesimpulan dan saran. Metode yang digunakan adalah content analysis atau analisis isi jurnal.

\section{HASIL DAN PEMBAHASAN \\ Pembelajaran Daring}

Inovasi - inovasi dalam dunia pendidikan yang ada selama ini hanya menjadi angan dan diterapkan pada sebagian lembaga yang dapat membaca situasi dan memiliki kemampuan. Kondisi pandemi yang tiba - tiba datang mengubah beberapa cara hidup sebagian besar masyarakat, menjadikan salah satu titik balik yang membuat sadar perlunya untuk siap pada perubahan, tidak terkecuali pada dunia pendidikan, salah satunya dengan beradaptasi dan mencoba inovasi yang ada. Inovasi pembelajaran yang yang selama ini sudah mulai dilakukan oleh beberapa lembaga dan saat ini menjadi semua lembaga pendidikan adalah pembelajaran daring. Pembelajaran daring saat ini dilakukan oleh semua lembaga pendidikan, tak terkecuali pendidikan anak usia dini.

Pendidikan anak usia dini termasuk salah satu pendidikan yang sangat jarang menggunakan pembelajaran daring. Hal ini menjadikan guru pendidikan anak usia dini harus mengalami perubahan pembelajaran yang drastis. Perubahan menuntut guru untuk siap dan mampu melakukan pembelajaran daring. Salah satu hasil penelitian menyatakan bahwa terdapat guru PAUD yang belum siap dalam melakukan pembelajaran daring pada masa pandemi covid-19 (Ayuni, Marini, Fauziddin, \& Pahrul, 2020). Ketidak siapan guru dipicu oleh beberapa faktor salah satunya adalah fasilitas yang tidak memadai dan juga anggapan bahwa pembelajaran daring sulit dilaksanakan.

Guru di Indonesia dirasa terlalu gagap dalam mengoperasikan teknologi untuk melakukan pembelajaran daring (Churiyah et al., 2020). Sejalan sengan penelitian lain yang menjelaskan ketidakmampuan guru dalam beradaptasi dalam pelaksanaan pembelajaran daring seperti masih menggunakan gaya mengajar yang biasa dengan media pembelajaran daring yang baru dan tidak berusaha mengembangkan kemampuan pedagogi untuk mampu menggunakan teknologi (Ncube, Dube, \& Ngulube, 2014). Namun mengadaptasi teknologi untuk pembelajaran daring tanpa melakukan perencanaan akan dapat mengakibatkan 
kegagalan dalam pembelajaran daring itu sendiri dan terlalu banyak menghabiskan biaya tanpa hasil yang baik (Clark \& Richard E Mayer, 2011). Guru harus mampu menyesuaikan diri dengan kondisi yang baru, dimana akan berhubungan dengan teknologi dan membutuhkan perencanaan yang tepat sehingga mampu melaksanakan pembelajaran daring yang efektif dan efisien. Pengukuran kesiapan terhadap kesiapan pembelajaran daring merupakan sebuah kunci dari terlaksananya pembelajaran daring yang efektif (Rohayani, Kurniabudi, \& Sharipuddin, 2015). Sebelum dilakukan pembelajaran daring perlu diketahui kesiapan para pemangku kepentin yaitu guru agar dapat mengasesmen penerapan pembelajaran daring dalam pendidikan (Ke, AlSaqqaf, \& Swanto, 2020). Tingkat kesiapan guru dalam melakukan pembelajaran daring merupakan faktor besar yang dapat mempengaruhi keberhasilan dan demi pembelajaran yang dapat terus dilakukan.

Berdasarkan kajian tentang urgensi kesiapan guru dalam pembelajaran daring menjelaskan bahwa penting sekali bagi sekolah dan guru itu sendiri untuk mengetahui tingkat kesiapannya dalam pelaksaanaan pembelajaran daring. Data atau informasi mengenai kesiapan guru dalam pembelajaran daring khususnya untuk guru pendidikan anak usia dini yang cenderung melakukan tatap muka dengan peserta didiknya dapat digunakan bagi pihak lembaga untuk menentukan hal apa yang perlu dilakukan agar pembelajaran daring berjalan dengan baik. Selain itu tingkat kesiapan guru dalam pembelajaran daring di lembaga pendidikan anak usia dini dapat membantu guru untuk merancang pembelajaran daring sesuai dengan kemampuan mereka dan tujuan pembelajaran agar pembelajaran bisa berjalan dengan baik.

\section{Indikator Kesiapan Guru Dalam Pembelajaran Daring}

Kesiapan guru dalam memang sangat diperlukan untuk memberikan pembelajaran daring. Saat ini mulai muncul banyaknya penelitian yang mengembangkan cara mengukur kesiapan guru dalam pembelajaran daring. Beberapa cara yang dituangkan dalam instrumen skala pengukuran berkaitan dengan faktor. Terdapat beberapa faktor yang menjadi kunci utama dalam kesiapan guru dalam pembelajaran daring dalah sikap, kopetensi pada teknologi, pedagogi dan cara mengajar, pelatihan dan kendala waktu (Phan \& Dang, 2017).

Beberapa skala untuk melakukan pengukuran kesiapan guru dalam pembelajaran pun banyak dikembangkan. Salah satu skala yang telah dikembangkan adalah Test Of Online Learning Success (TOOLS) yang dikembangkan oleh Kerr dkk (dalam Kauffman, 2015). Skala TOOLS terdiri dari beberapa komponen yang dinilai yaitu computer skills, independent learning, dependent learning, need for online delivery dan academic skill. Selain TOOLS, pengukuran kesiapan pembelajaran daring banyak dikembangan pada tingkat pendidikan tinggi. Electronic Learning Readiness (ELR) dikembangkan oleh Okecth, dkk (Ha, JM, \& An, 2014) melihat kesiapan pembelajaran daring dari sisi teknologi dan kesiapan budaya. Kuesioner kesiapan guru dan murid dalam pembelajaran daring dikembangan dengan melihat beberapa bagian oleh Afolabi, yaitu section A untuk melihat informasi personal, section $\mathrm{B}$ melihat ketersediaan internet dan perangkat daring, section $\mathrm{C}$ mencari tahu tentang Information and Communication Technology dan section D melihat kesiapan dasar penggunaan metode pembelajaran daring (Afolabi, 2015). Selain itu Gay (Gay, 2016) menjelaskan faktor yang mempengaruhi kesiapan guru dalam pembelajaran daring berada pada beberapa komponen yaitu technical skill, pedagogical skill, dan lifestyle skill. 
Sebagian besar yang melakukan pengembangan alat ukur kesiapan pembelajaran daring berasal dari pendidikan tinggi. Namun terdapat skala yang dikembangkan dengan melibatkan guru sekolah dasar dan sekolah menengah pertama, yaitu skala Teacher Readiness for Online Learning Measrue (TROLM), (Hung, 2015). Pada skala TROLM melihat pada 4 jenis dimensi yaitu Communication self-efficacy (CSE), Institutional support (IS), Self-directed learning (SDL), dan Learning transfer self-efficacy (LTSE).

Bila dilihat dari beberapa skala maupun instrument yang dikembangkan untuk melihat kesiapan pembelajaran daring khususnya untuk guru, memiliki caranya masing masing untuk mengukur. Indikator - indikator yang diukur meliputi ranah sosial emosional, kognitif, pedagogi, kemampuan penggunaan teknologi serta kemampuan berkomunikasi. Bila dilihat dari indikator yang ada, masing - masing skala memiliki perbedaan sesuai dengan kebutuhan dan karakteristik subjek dan lingkungan subjek. Hal tersebut mengindikasikan bahwa pembelajaran daring harus dilaksanakan sesuai dengan sosio demografi dan tingkat kesiapan dari masing - masing pelaksana, khususnya guru (Mirke, Cakula, \& Tzivian, 2019). Skala yang sesuai dengan keadaan populasi akan mampu mengukur kesiapan guru lebih tepat dan menghasilkan perencanaan pembelajaran daring lebih baik.

\section{KESIMPULAN}

Perubahan cara pelaksanaan pembelajaran yang terjadi mengakibatkan inovasi pembelajaran daring yang selama ini dilakukan oleh lembaga tertentu saat harus dilakukan semua jenis lembaga pendidikan, termasuk pendidikan anak usia dini. Guru harus siap dalam melaksanakan pembelajaran daring. Kesiapan guru dalam pembelajaran daring ini akan mempertahankan tujuan dan kualitas pembelajaran. Perlu adanya pengukuran kesiapan guru dalam pembelajaran daring sebelum pihak lembaga membentuk sistem pembelajaran. Kesiapan guru dalam pembelajaran akan menentukan kesiapan lembaga untuk melakukan pembelajaran daring pula. Kesiapan guru dalam pembelajaran daring di lembaga pendidikan anak usia ini dapat diukur melalui indikator - indikator yang meliputi ranah sosial emosional, kognitif, pedagogi, kemampuan penggunaan teknologi serta kemampuan berkomunikasi yang disesuaikan dengan kebutuhan dan karakteristik subjek yang lingkungan subjek. Sehingga alat ukur yang digunakan mampu memberikan data yang tepat agar dapat melakukan pembelajaran daring dengan baik dan mampu mengembangkan kemampuan anak.

\section{DAFTAR PUSTAKA}

Afolabi, A. A. (2015). Availability of Online Learning Tools and the Readiness of Teachers and Students towards it in Adekunle Ajasin University, Akungba-akoko, Ondo State, Nigeria. Procedia - Social and Behavioral Sciences, 176, 610-615. https://doi.org/10.1016/j.sbspro.2015.01.517

Ayuni, D., Marini, T., Fauziddin, M., \& Pahrul, Y. (2020). Kesiapan Guru TK Menghadapi Pembelajaran Daring Masa Pandemi Covid-19. Jurnal Obsesi : Jurnal Pendidikan Anak Usia Dini, 5(1), 414. https://doi.org/10.31004/obsesi.v5i1.579

Churiyah, M., Sholikhan, S., Filianti, F., \& Sakdiyyah, D. A. (2020). Indonesia Education Readiness Conducting Distance Learning in Covid-19 Pandemic Situation. 
International Journal of Multicultural and Multireligious Understanding, 7(6), 491. https://doi.org/10.18415/ijmmu.v7i6.1833

Clark, R. C., \& Richard E Mayer. (2011). E-Learning and the Science of Instruction. San Francisco: Pfeiffer.

Dong, C., Cao, S., \& Li, H. (2020). Young children's online learning during COVID-19 pandemic: Chinese parents' beliefs and attitudes. Children and Youth Services Review, 118(September), 105440. https://doi.org/10.1016/j.childyouth.2020.105440

Gay, G. H. E. (2016). An assessment of online instructor e-learning readiness before, during, and after course delivery. Journal of Computing in Higher Education, 28(2), 199-220. https://doi.org/10.1007/s12528-016-9115-z

Ha, O., JM, N., \& An, W. (2014). E-Learning Readiness Assessment Model in Kenyas' Higher Education Institutions: A Case Study Of University of Nairobi. International Journal of Scientific Knowledge, 5(6), 29-41. Retrieved from www.ijsk.org/ijsk

Hung, M. L. (2015). Validation of the teacher readiness for online learning measure. Proceedings - IEEE 15th International Conference on Advanced Learning Technologies: Advanced Technologies for Supporting Open Access to Formal and Informal Learning, ICALT 2015, 361-363. https://doi.org/10.1109/ICALT.2015.28

Kauffman, H. (2015). A review of predictive factors of student success in and satisfaction with online learning. Research in Learning Technology, 23(1063519), 1-13. https://doi.org/10.3402/rlt.v23.26507

Ke, H., AlSaqqaf, A., \& Swanto, S. (2020). E-learning readiness among English language teachers in Sabah, Malaysia: A pilot study, 2(September), 120-127.

Koo, A. C. (2008). Factors affecting teachers' perceived readiness for online collaborative learning: A case study in Malaysia. Educational Technology and Society, 11(1), 266278.

Mirḳe, E., Cakula, S., \& Tzivian, L. (2019). Measuring teachers-as-learners' digital skills and readiness to study online for successful e-learning experience. Journal of Teacher Education for Sustainability, 21(2), 5-16. https://doi.org/10.2478/jtes-2019-0013

Ncube, S., Dube, L., \& Ngulube, P. (2014). E-learning readiness among academic staff in the Department of Information Science at the University of South Africa. Mediterranean Journal of Social Sciences, 5(16), 357-366. https://doi.org/10.5901/mjss.2014.v5n16p357

Nurdin, N., \& Anhusadar, L. (2020). Efektivitas Pembelajaran Online Pendidik PAUD di Tengah Pandemi Covid 19. Jurnal Obsesi : Jurnal Pendidikan Anak Usia Dini, 5(1), 686. https://doi.org/10.31004/obsesi.v5i1.699

Phan, T. T. N., \& Dang, L. T. T. (2017). Teacher Readiness for Online Teaching: A Critical Review. Int. J. Open Distance E-Learn. IJODeL, 3(1), 1-16. Retrieved from http://ijodel.com/wp-content/uploads/2017/12/001_Phan_Dang.pdf

Rohayani, A. H. H., Kurniabudi, \& Sharipuddin. (2015). A Literature Review: Readiness Factors to Measuring e-Learning Readiness in Higher Education. Procedia Computer Science, 59(January 2020), 230-234. https://doi.org/10.1016/j.procs.2015.07.564 


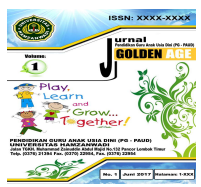

Sum, T. A., \& Taran, E. G. M. (2020). Kompetensi Pedagogik Guru PAUD dalam Perencanaan dan Pelaksanaan Pembelajaran. Jurnal Obsesi : Jurnal Pendidikan Anak Usia Dini, 4(2), 543-550. https://doi.org/10.31004/obsesi.v4i2.287

Tabi'in, A. (2020). Problematika Stay At Home Pada Anak Usia Dini Di Tengah Pandemi Covid 19. Jurnal Golden Age, 04(1), 190-200.

Waryanto, N. H., \& Setyaningrum, W. (2014). E-Learning Readiness In Indonesia : A Case Study In Junior High School Yogyakarta. International Seminar on Innovation in Mathematics and Mathematics Education 1st ISIM-MED, 1, 645-654. 